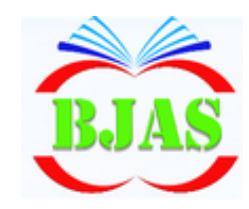

Available online at http://bajas.edu.iq https://doi.org/10.37077/25200860.2019.267 College of Agriculture, University of Basrah

ISSN $1814-5868$

Basrah J. Agric. Sci., 32(Spec. Issue 2): 183-192, 2019
Basrah Journal of Agricultural Sciences

\title{
Using of Extracted Carnosine Camel Meat to Improving some Quality Traits of Cold-Preserved Meat Patties
}

\author{
Aliaa J. Shabeeb* \& Ameera K. Nassir \\ Animal Production Department, Agriculture College, University of Basrah, Iraq. \\ *Corresponding author e-mail: aliaa.jary@yahoo.com \\ Received 19 September 2019; Accepted 18 November 2019; Available online 22 November 2019
}

\begin{abstract}
The aim of this study is to extract carnosine from camel meat by using alcohol and the dialysis extraction method in Laboratory distilled water and added the extract to the minced beef pills at two concentrations (50 and 100) $\mathrm{gm} .100^{-1} \mathrm{~g}$ meat to test the possibility of extending the preservation period at $4{ }^{\circ} \mathrm{C}$. The carnosine extract was diagnosed in a Highly Efficient Liquid Chromatography method (HPLC). Chemical tests were conducted for minced beef, which included the number of peroxides, the values of thiobarbituric acid (TBA), free fatty acids percentage, and microbial tests, which included the total bacteria count and psychrophilic bacteria as well as to the sensory test that including colour, flavour, tenderness, juiciness and general acceptability. The results showed a significant decrease in the values of chemical tests (peroxide, thiobarbituric acid and fatty acids ratio), and microbial tests (the total bacteria count and psychrophilic bacteria) of minced beef treated with carnosine extracted compared with the control sample. The samples treated with different concentrations of camel carnosine recorded the highest sensory evaluation levels compared to the control sample for the same preservation period.
\end{abstract}

Keywords: Carnosine extraction, Camel meat, Improving meat.

\section{Introduction}

Several studies have confirmed the presence of vital compounds in the muscles of mammals and birds. They are low molecular weight peptides, which are directly extracted by organic solvents as a supplement to enhance nutritional value and also used in the maintenance of human health (Artioli et al., 2019). Low molecular weight binary peptides are made up from histidine amino acids, betaalanin that have multiple shapes and images according to their natural sources such as carnosine (beta-alanyl-L-histidine), homocarnosine carnosine similarities (homocarnosine)
Gamma-amino-butyrl-L-histidine) and Anserine (beta-alanyl-methyl- L. histidine), Carcinine, which consists of histamine bio amine after removing the group carboxylase of histidine amino acid and it's associated with alanine that is present inside the living organism as regulated agents that maintain the balance of the $\mathrm{pH}$ in the blood (Boldyrev et al., 2013; Jones, 2017). They limit or prevent oxidative processes that occur inside the body (Sila \& Bougatef., 2016). As a result of its decrease in the body with an increase of age and the possibility of obtaining it from food because meat proteins are a rich source of these peptides. 
The current study aimed to extract carnosine from camel meat and adding it to meat tablets to improve some of its qualities and reduce its oxidation indicators.

\section{Materials \& Methods}

\section{Camelus dromedarius}

Camel meat was obtained from the local markets in Basrah governorate Zubair region with ages ranging from one year to one year and three months. The pieces of meat were separated from the fat and bone. It was cut into small pieces and packed with bags of polyethylene and then frozen at $-18{ }^{\circ} \mathrm{C}$ until the use of the extraction process.

\section{Alcohol extract of carnosine}

Carnosine extraction was performed according to the method used by Auh et al. (2010) mentioned in Kim et al. (2014) with some slight modifications by placing samples in the refrigerator at $4 \pm 1{ }^{\circ} \mathrm{C}$ for 24 hours. Dissolving $250 \mathrm{~g}$ of frozen samples at the rate (1:24) of an alcohol solution with a concentration of $35 \%$, then incubated at a temperature of $25^{\circ} \mathrm{C}$, with stirring for 1-3 hours. The mixture placed at a $14000 \mathrm{Xg}$ centrifuge for 30 minutes. Take $300 \mathrm{ml}$ of filtrate and mixed with $900 \mathrm{ml}$ of alcohol cold ethanol ( $35 \%$ concentration). Placed the mixture at the refrigerator at a temperature of $4 \pm 125^{\circ} \mathrm{C}$ for 30 minutes, a centrifuged for 30 minutes and filtered using Whatman No.4 filter paper. Samples were concentrated from $1000 \mathrm{ml}$ to $200 \mathrm{ml}$ using the rotary evaporator at $40{ }^{\circ} \mathrm{C}$, then placed in a cut-off $3.5 \mathrm{kD}$ dialysis bag against a quantity of distilled water for 24 hours with replacement every four hours (Kambourova et al., 2001) described in (Al-Taee, 2015).

\section{Carnosine diagnosis}

Carnosine was diagnosed with camel meat according to the method mentioned in Gopalakrishnan et al. (1999) with Highefficiency Liquid Chromatography (HPLC) technique.

\section{Prepare beef patties:}

The meat patties were prepared after the minced lean meat and divided into the following treatments:

First treatment: without adding carnosine. The second treatment: added camel carnosine at a concentration of $50 \mathrm{mg} 100 \mathrm{~g}^{-1}$ minced lean meat.

The third treatment: added camel carnosine at a concentration of $100 \mathrm{mg} .100 \mathrm{~g}^{-1}$ minced lean meat.

After the manufacturing process, the meat patties placed in vacuum-evacuated polyethylene bags. The bags were well wrapped and kept cool at $4{ }^{\circ} \mathrm{C}$.

\section{Chemical tests:}

\section{Peroxide value:}

The peroxide value was estimated according to the Al-Aswad (2000) method. 3g of minced meat was weighed and added to $30 \mathrm{ml}$ of the mixture of glacial acetic acid and chloroform with a ratio of $3: 2 ; 5 \mathrm{ml}$ of saturated potassium iodide, $20 \mathrm{ml}$ of distilled water and a few drops of starch indicator. Then, the mixture was titrated with a 0.001 standard sodium thiosulfate solution until the disappearance of the blue colour. The peroxide value was estimated by the following formula:

$$
\text { Poxide value }=\frac{\left(\mathrm{Na}_{2} \mathrm{~S}_{3} \mathrm{O}_{4} \mathrm{ml} \times \mathrm{N} \times 1000\right)}{(\text { Wt. of Sample gm })}
$$




\section{Measuring the values of thiobarbituric acid} (TBA):

Mehran (1976) in Jalali et al. (2015) method was used to estimate the value of TBA. Taking $5 \mathrm{~g}$ of minced meat and dissolved in $10 \mathrm{ml}$ of chloroform and $10 \mathrm{ml}$ of $0.07 \%$ solution of thiobarbituric acid (in water mixed with the same size of acetic acid) added to it. The centrifuge of the mixture was
$1000 \mathrm{rpm}$ for 5 minutes. The clear solution was taken and absorbance was measured at 532 wavelengths at room temperature. The value of TBA was estimated to be a malonaldehyde (MDA) $\mathrm{mg} \mathrm{kg}^{-1}$.

The concentration value was estimated by the following formula:

Concentration of malonaldehyde $\left(\mathrm{mg} \mathrm{kg}^{-1}\right)=$ absorbance $\times 7.8$

\section{Percentage of free fatty acids}

Free fatty acids (FFA) were estimated based on the Al-Aswad (2000) method. $3 \mathrm{~g}$ of minced meat was weighed and added to $50 \mathrm{ml}$ of ethanol alcohol with a concentration of 99.9\%. Drops of the Phenolphthalein index were added after being heated in a water bath

$$
\text { Free fatty acid }=\frac{T(A-B) \times N \times 282 \times 100}{\text { WT.of Sample } \times 1000}
$$

$\mathrm{A}=$ number of $\mathrm{KOH}$ millilitres with fat or oil sample.

$\mathrm{B}=$ number of $\mathrm{KOH}$ millilitres with plank sample.

$282=$ molecular weight of oleic acid

\section{Bacteriological analysis}

The method described in Al-Aswad (2000) was used to estimate the total number of bacteria. The Nutrient Agar culture media were used.

\section{Psychrophilic bacteria count}

Nutrient Agar media was used to calculate the number of psychrophilic bacteria as the dishes were incubated at a temperature at $7^{\circ} \mathrm{C}$. The total number of psychrophilic bacteria were calculated according to Andrews (1992) method. Johnston (1997). until boiling. Titrated the mixture with $0.1 \mathrm{M}$ potassium hydroxide solution until change solution colour to light pink. The percentage of free fatty acids was estimated by the formula:

\section{Sensory evaluation:}

The meat patties fried at a hot plate for 8 minutes, with continuous stirring (Berry, 1991). The sensory evaluation of the meat patties was carried by experienced residents in the Animal Production Department, College of Agriculture, University of Basrah. The assessment included colour, flavour, juiciness, tenderness, and general acceptability according to Krochta \&

\section{Statistical analysis}

The results were statistically analyzed using Complete Randomized Design (CDR) within the Ready Statistical Program (SPSS, 2018) and compared the results using the least 
significant difference (RLSD) at a significant level of 0.05 (Al-Rawi \& Khalafallah, 2000).

\section{Results \& Discussion}

\section{Diagnosis of camel meat carnosine}

The results of the test of alcoholic carnosine diagnosed with HPLC showed the value of

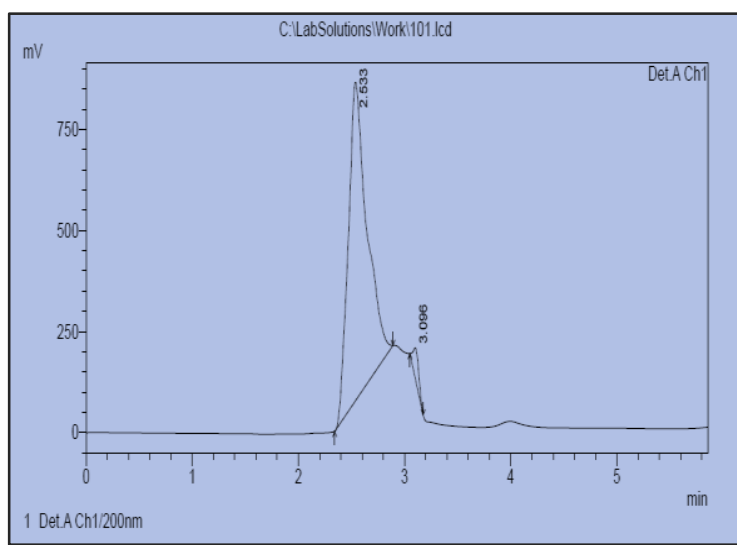

A

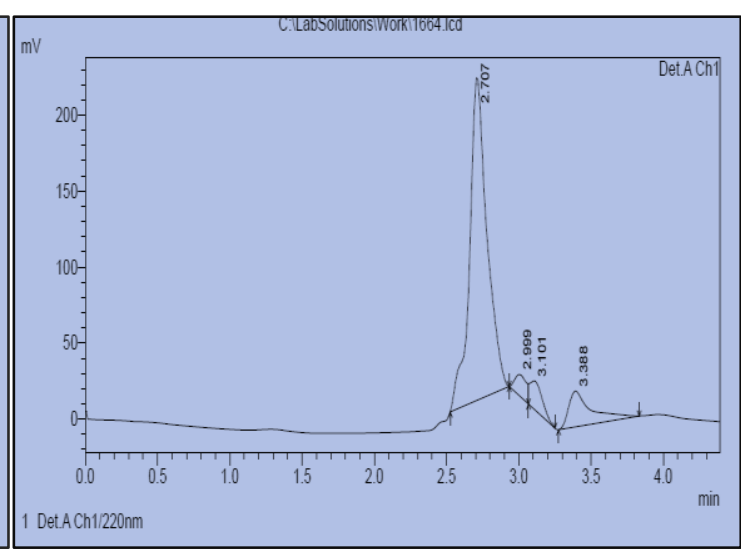

B

Fig. (1): HPLC for carnosine extract: A-carnosine standard, B- carnosine for camel meat.

\section{Chemical tests for beef patties}

Peroxide value (PV)

Table (1) showed a significant decrease $(P<0.05)$ on peroxide values in meat patties treated with carnosine camel meat at concentrations of 50 and $100 \mathrm{mg} / \mathrm{ml}$ compared to the control sample. The value of $\mathrm{PV}$ in the control treatment increased from 1.133 meq. $\mathrm{kg}^{-1}$ meat to 2.833 meq. $\mathrm{kg}^{-1}$ meat after three days of cryopreservation. While PV values for treatment with camel meat carnosine on the 8 th cooling conservation day were 2.933 and 2.773 meq. $\mathrm{kg}^{-1}$ meat for the camel meat carnosine with a detention time of 2.707 minutes and a concentration of $55313.72 \mu \mathrm{g}$. $\mathrm{g}^{-1}$, while the standard carnosine at the time of its detention was 2.532 (fig. 1). 
activity which had the ability to delay oxidative processes and prevent free radical formation (Chen \& Li., 2012).

\section{Value of thiobarbituric acid (TBA):}

Table (2) showed a significant increase in the TBA values for meat samples with increasing cryopreservation. A significant difference was observed between the control sample and the samples treated with carnosine extracted from camel meat. The first record for all studied samples was $0.562 \mathrm{mg} \mathrm{MN} \cdot \mathrm{kg}^{-1}$ meat. The TBA values increased gradually during the preservation period from the third day to the tenth day. The TBA value was 0.676 and $0.620 \mathrm{mg} \mathrm{MN} . \mathrm{kg}^{-1}$ meat on the third day of cryopreservation when was treated with the concentrations of 50 and $100 \mathrm{mg} \cdot \mathrm{mL}^{-1}$, respectively. However, it was considered as a significantly low value $(P<0.05)$ when it compared to the control treatment of 0.961 mg MN.kg ${ }^{-1}$ meat for the same period of preservation.

On the sixth day of conservation, the value of TBA was 0.697 and $0.643 \mathrm{mg} \mathrm{MN} \cdot \mathrm{kg}^{-1}$ meat in the samples to which camel carnosine was added to concentrations (50 and 100) $\mathrm{mg} .100 \mathrm{~g}^{-1}$, respectively, while the control sample recorded $1.326 \mathrm{mg} \mathrm{MN} . \mathrm{kg}^{-1}$ meat. The
TBA values continued to significant rise with the average values on the eighth day of 1.252 and $0.646 \mathrm{mg} \quad \mathrm{MN}_{\mathrm{kg}}^{-1}$ meat for the concentrations (50 and 100) mg.100 $\mathrm{g}^{-1}$ respectively. Whereas, TBA value for the control sample was 2, $240 \mathrm{mg} \mathrm{MN} \cdot \mathrm{kg}^{-1}$ of meat, exceeding the acceptable limits.

TBA meat patties samples treated with camel meat carnosine were within the acceptable limits after the tenth day of conservation, with an average concentration 50 and $100 \mathrm{mg} \cdot 100 \mathrm{~g}^{-1}(1.217 \mathrm{mg}$ and 0.884

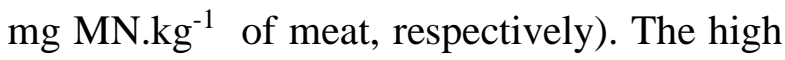
antioxidant effectiveness is due to the structural properties of peptides such as the low molecular weight of amino acids involved in their synthesis. The sequence in the chain of natural amino acids, some of which are like water-haters, as this structure is available in peptides increases the effectiveness of the antioxidant (Wang et al., 2014).

\section{Percentage of free fatty acid:}

The results of the table (3) showed a significant decrease in the percentage of free fatty acid when treating the meat pills with carnosine camel meat at the concentration of 50 and $100 \mathrm{mg} 100 \mathrm{~g}^{-1}$. On the sixth day of conservation, the percentage of free fatty

Table (2): The effect of camel meat carnosine on the value of TBA in patties Refrigerated meat $\left(4^{\circ} \mathrm{C}\right)$.

\begin{tabular}{llll}
\hline $\begin{array}{l}\text { Retention } \\
\text { period (day) }\end{array}$ & Treatment & & \\
\cline { 2 - 4 } & Control & $50 \mathrm{mg} / \mathrm{ml}$ & $100 \mathrm{mg} / \mathrm{ml}$ \\
\hline 0 & 0.562 & 0.562 & 0.562 \\
\hline 3 & 0.961 & 0.676 & 0.620 \\
\hline 6 & 1.326 & 0.967 & 0.643 \\
\hline 8 & 2.240 & 1.252 & 0.646 \\
\hline 10 & 2.419 & 1.217 & 0.884 \\
\hline RLSD 0 .126 & & & \\
\hline
\end{tabular}


acids 0.36 and 0.31 for concentrations 50 and 100 respectively, while the control treatment was $0.68 \%$. On the eighth day, control treatment was $1.19 \%$, while samples treated with camel meat carnosine were within the limits of the specifications 0.46 and $0.43 \%$ for concentrations 50 and $100 \mathrm{mg} \cdot 100 \mathrm{~g}^{-1}$.

The percentages of free fatty acids for meat samples treated with camel meat carnosine continued within the standard specifications after ten days of conservation, registering 0.75 and 0.62 for concentrations 50 and 100 mg. $100 \mathrm{~g}^{-1}$, respectively.
The results obtained indicate that carnosine extracted from camel meat lead to the process of fatty analysis at the beginning of the refrigerant conservation period and for all concentrations until the tenth day. This may be due to the presence of peptides, which are act as a source of positive-charged basal amino acids such as histidine in the end $\mathrm{N}$, which contributes to reducing bacterial growth (Huang \& Wu 2010), thereby limiting the growth of bacteria that secrete the enzyme of lipase, which acts as a decomposition.

Table (3) Effect of different concentrations of camel meat carnosine on percentage for fatty acids for cold-preserved beef patties.

\begin{tabular}{llll}
\hline Retention & Treatment & & \\
\cline { 2 - 4 } period (day) & Control & $50 \mathrm{mg} / \mathrm{ml}$ & $100 \mathrm{mg} / \mathrm{ml}$ \\
\hline 0 & 0.21 & 0.21 & 0.20 \\
\hline 3 & 0.43 & 0.31 & 0.25 \\
\hline 6 & 0.68 & 0.36 & 0.31 \\
\hline 8 & 1.20 & 0.46 & 0.43 \\
\hline 10 & 1.46 & 0.75 & 0.62 \\
\hline RLSD 0.121 & & & \\
\hline
\end{tabular}

Total numbers of bacteria camel carnosine:

The results of the fig. (2) showed the total numbers of bacteria in beef patties treated with carnosine extracted from camel meat with concentration 50 and $100 \mathrm{mg} .100 \mathrm{~g}^{-1}$ meat and kept by cooling at $4^{\circ} \mathrm{C}$. A significant decrease $(P<0.05)$ in the total number of bacteria in patties meat treated with carnosine extracted compared with the control samples. While the numbers of bacteria at the beginning of the trial were $\left(88.7 \times 10^{3}{\mathrm{CFU} . \mathrm{g}^{-}}^{-}\right.$ $\left.{ }^{1}\right)$, on the third day of cryopreservation. The total numbers of bacteria were (66 and $36.3 \times$ $10^{3} \mathrm{CFU}^{-1} \mathrm{~g}^{-1}$ ) for the samples treated with carnosine at the concentration 50 and 100 mg.100 $\mathrm{g}^{-1}$ meat, respectively. While the number of bacteria in the control samples was $164.7 \times 10^{3} \mathrm{CFU}^{-1}$ on the sixth day of conservation. The inhibitory effect of carnosine continued with increased concentration of $108 \times 10^{3}$ and $59 \times 10^{3} \mathrm{CFU}_{\text {. }}{ }^{-1}$ for 50 and $100 \mathrm{mg} \cdot 100 \mathrm{~g}^{-1}$ meat respectively, while the control sample was $\left(197.3 \times 10^{3}\right.$ CFU.g $\left.{ }^{-1}\right)$. The gradual increase to reach total number of bacteria for days 8 and 10 of the conservation period was $116 \times 10^{4}$ and 60 $\times 10^{4}$ and $137 \times 10^{4}$ and $171.7 \times 10^{4} \mathrm{CFU} \cdot \mathrm{g}^{-1}$ for concentrations 50 and $100 \mathrm{mg} .100 \mathrm{~g}^{-1}$ meat while the control sample during these periods of the same conservation was $\left(198.7 \times 10^{5}\right.$ and $\left.397 \times 10^{5}\right) \mathrm{CFU}_{\mathrm{g}}{ }^{-1}$.

The addition of carnosine peptides to minced beef tablets may assist to reduce the number of bacteria-contaminated with meat.

The inhibition effect of carnosine peptides to the numbers of bacteria may be due to the interaction of the peptide with the surface charge of cells and affects the permeability of 


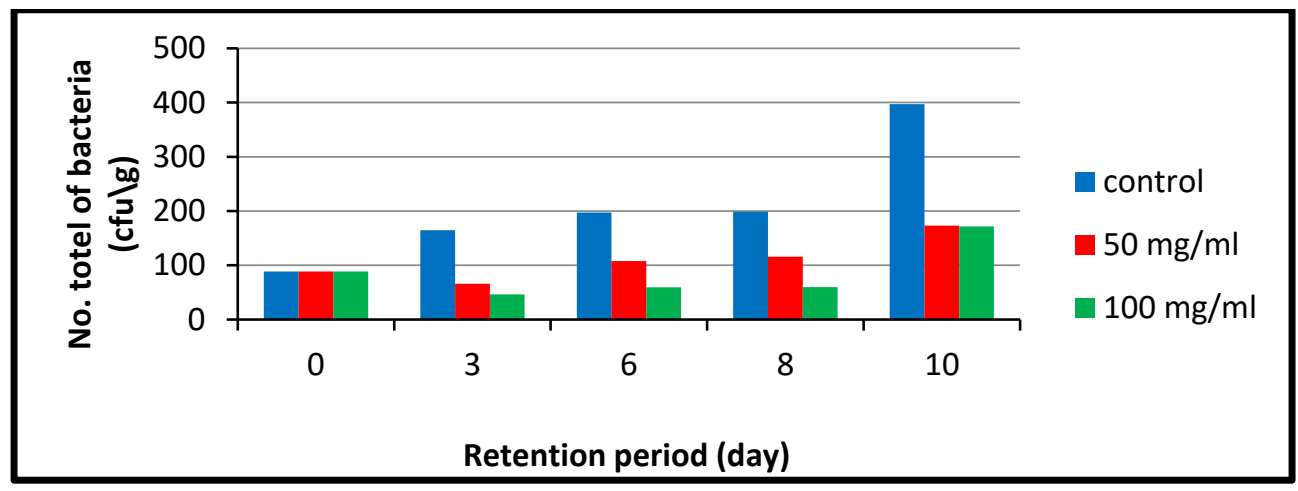

Fig. (2): Total bacterial count $\left(\mathrm{CFU} \cdot \mathrm{g}^{-1}\right)$ in beef patties treated with different concentrations of carnosine cold-preserved camel meat $\left(4^{\circ} \mathrm{C}\right)$.

cellular membranes or may cause holes or rupture of membranes and causes the cell death (Brogden, 2005).

\section{Psychrophilic bacteria count}

The results presented in fig. (3) showed a significant difference $(P<0.05)$ in the numbers of cold-loving bacteria on beef pills treated with carnosine extracted from camel meat and compared with the control samples as the duration of the preservation progress by cooling. The results showed lower significant $(P<0.05)$ numbers of bacteria on the third day of conservation and recorded 62.7 and $55 \times$ $10^{3}$ CFU.g ${ }^{-1}$ for concentrations 50 and 100
Mg.100 $\mathrm{g}^{-1}$ meat respectively. While the control treatment was $112 \times 10^{3} \mathrm{CFU}^{-1}$. On the sixth day of cryopreservation, the numbers of bacteria were 111.3 and $65.3 \times 10^{3} \mathrm{CFU} . \mathrm{g}^{-1}$ for concentrations 50 and $100 \mathrm{mg} .100 \mathrm{~g}^{-1}$ meat, respectively. While the treatment of control increased to $178.7 \times 10^{4} \mathrm{CFU}_{\mathrm{g}^{-1}}$ and as the conservation period progressed. The numbers of cold-loving bacteria gradually increased in days 8 and 10 to $118.7 \times 10^{4}$, $69 \times 10^{4}, \quad 252.3 \times 10^{4}$ and $184.7 \times 10^{4}$ respectively for the concentration 50 and 100 $\mathrm{mg} .100 \mathrm{~g}^{-1}$. However, these numbers were lower compared to the control treatment, which was $235.3 \times 10^{5}$ and $314.7 \times 10^{5} \mathrm{CFU} . \mathrm{g}^{-1}$ for the same time periods.

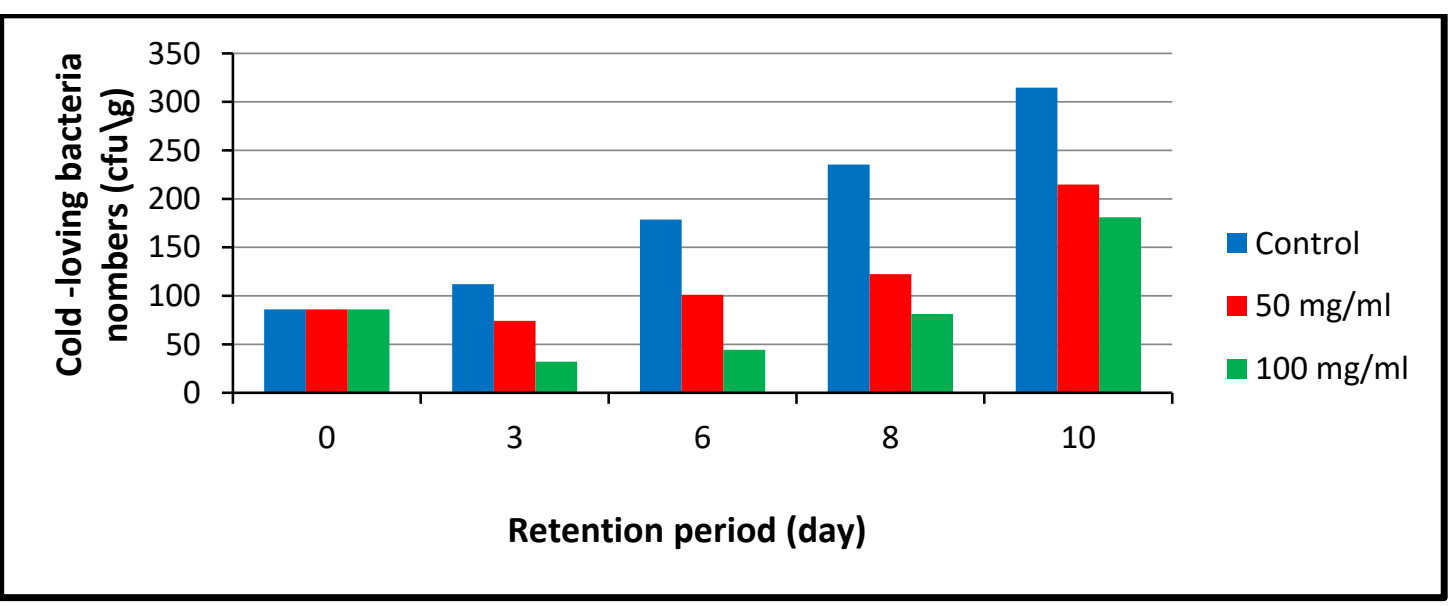

Fig. (3) of the preparation of psychrophilic bacteria (CFU.g $\left.{ }^{-1}\right)$ in beef discs treated with different concentrations of carnosine cold-preserved camel meat $\left(4^{\circ} \mathrm{C}\right)$. 
The results in the fig. (3) showed that the concentration $100 \mathrm{mg} .100 \mathrm{~g}^{-1}$ meat superior in reducing the numbers of psychrophilic bacteria with an average of $92 \times 10^{3} \mathrm{CFU}^{-1} \mathrm{~g}^{-1}$ while the average concentration $50 \mathrm{mg} .100 \mathrm{~g}^{-}$ 1 meat is $126.2 \times 10^{3} \mathrm{CFU}_{\mathrm{g}}{ }^{-1}$.

\section{Sensory evaluation of beef patties}

The results were shown in the table (4) revealed the sensory evaluation of beef meat treated with the carnosine extracted from camel meat at 50 and $100 \mathrm{mg} .100 \mathrm{~g}^{-1}$ meat kept cooled at $4{ }^{\circ} \mathrm{C}$ for the period of four days. The statistical analysis results showed a significant difference in the degrees of sensory evaluation of the minced meat treated with the carnosine extracted from camel meat compared with the control samples. It was noted that the meat patties added to the carnosine camel meat with two concentrations 50 and $100 \mathrm{mg} .100 \mathrm{~g}^{-1}$ meat gave higher ratings for the characteristic of colour, flavour, juice and tenderness compared to the control. The reason for the rise of some degrees of sensory evaluation may be due to the nitrogen or non-protein nitrogen (NPN), which is part of the water extract of the meat and produces non-protein substances that in turn form the disintegration of proteins. Fresh processed meat plays a big role in the appearance of sensory traits in meat, as peptides considered form the main part among non-protein ads. Protein degradation affects both texture and flavour development due to the emergence of many compounds with low molecular weight, including peptides such as carnosine, enserine, amino acids, aldehyde organic acids, and amino which are important flavouring ingredients (Dyup, 2011). These findings are similar to those of Mokhtar et al. (2014) when the $4{ }^{\circ} \mathrm{C}$ minced beef tablets were treated with carnosine and ketosis.

Table (4): Sensory evaluation of beef tablets manufactured with the addition of carnosine for four days by cooling $4^{\circ} \mathrm{C}$.

\begin{tabular}{|c|c|c|c|c|c|c|}
\hline \multirow[t]{2}{*}{ treatments } & \multirow{2}{*}{$\begin{array}{l}\text { Concentration } \\
100 \mathrm{mg} \text { meat }\end{array}$} & \multicolumn{5}{|c|}{ Parameter } \\
\hline & & Colour & Flavor & Juiciness & Tenderness & $\begin{array}{l}\text { general } \\
\text { acceptance }\end{array}$ \\
\hline Control & 0 & 6.83 & 5 & 5.16 & 6.17 & 6 \\
\hline \multirow{2}{*}{$\begin{array}{l}\text { Camel meat } \\
\text { carnosine }\end{array}$} & 50 & 6.16 & 6.50 & 6 & 6.50 & 7 \\
\hline & 100 & 6.16 & 6.50 & 6 & 6.50 & 6.83 \\
\hline RLSD & & 0.576 & 1.201 & 0.333 & 0.745 & 0.333 \\
\hline
\end{tabular}

\section{Conclusions:}

The results showed the possibility of separating carnosine from camel meat and diagnosing it in highly-efficient Liquid Chromatography. Extracted carnosine can be added to chilled minced meat patties to decrease oxidant indicators through the number of peroxide and TBA acid values. A significant decrease in the percentage of free fatty acids of chilled minced beef patties treated with carnosine extracted from camel meat compared to the control treatment, as well as the use of carnosine extracted from camel meat has reduced the rise in meat pollution. There is a reduction in the total number of bacteria and bacteria loving the cold, as the results of the sensory evaluation showed that the use of carnosine extracted 
from camel meat led to improved sensory qualities of chilled beef patties that included colour, flavour, juice, tenderness, and general acceptance.

\section{Acknowledgements}

We offer sincere thanks and appreciation to the Deanship of the Faculty of Agriculture and the head of the Department of Animal Production and to all members of the Department of Animal Production, especially Dr. Sabah K. Marzouk for his assistance in statistical analysis.

\section{References:}

Al-Rawi, K.M. \& Khalafallah, A.M. (2000). Design \& Analysis of Agricultural Experiments. $2^{\text {nd }}$ ed. The Book House for Printing and Publishing, Univ. Mosul: 488pp. (In Arabic).

Al-Taee, A. (2015). Production of Polyglutamic Acid Using Bacillus subtilis, LAP Lambert Academic Publishing., Heinrich-Böking. Str. 6-8, 66121 Saarbrucken, Dev̄tschland: 112pp.

Andrews, W.C. (1992). Manual of Food Quality Control, 4- Rev.1. Microbiological Analysis, FAO, Food \& Nutr. pap, No. 14, Rev-1: 336pp.

Al-Aswad, M.B. (2000). Practical Manual of Meat Technology. $2^{\text {nd }}$ edn. Daar Al-Kutob for Printing and Press. Univ. Mosul: 140pp. (In Arabic).

Artioli, G.G.; Sale, C. \& Jones, R.L. (2019). Carnosine in health and disease in European. J. Sport Sci., 19: 30-39.

Auh, J.H.; Namgung, N.; Shin, K.S.; Park, S.W. \& Paik, I.K. (2010). Effects of supplementary blood meal on the content of carnosine and anserine in broiler meat. J. Poult. Sci., 47: 302-309.
Berry, B.W. (1991). Effects of soy protein \& freezing treatments on cooking loss \& composition of beef patties. J. Muscle Foods, 2: 105-116.

Boldyrev, A.; Aldini, G. \& Derave, W. (2013). Physiology and Pathophysiology of carnosine. Physiol. Rev., 93: 1803-1845.

Brogden, K.A. (2005). Antimicrobial Peptides: pore formers or metabolic inhibitors in bacteria Nat. Rev. Microbial., 3: 238-250.

Chen, M. \& Li, B. (2012). The effect of molecular weights on the survivability of casein-derived antioxidant peptides after the simulated gastrointestinal digestion. Innov. Food Sci. Emerg. Technol., 16: 341-348.

Dyup, G. (2011). Determines the composition and nutritional value of Syrian singlehumping camel meat. Ph. D. Thesis. Fac. Agric. Univ. Aleppo: 103pp.

Gopalakrishnan, J.; Decker, E.A. \& Means, W.J. (1999). Antioxidant activity of mechanically separated pork extracts. Meat Sci., 52: 101-110.

Huang, F.J. \& Wu, W.T. (2010). Purification and characterization of a new peptide (s8300) from shark liver. J. Food Biochem., 34(5): 962-970.

Jalali, M.S.R.; Niazmand, R. \& Shahidi Noghabi, M. (2015). Antioxdative activity of purslane (Portulaca tolerances L.) see hydroalcoholic extract on the stability of soybean oil. .J. Agric. Sci. Technol., 17(6): 1473-1480 .

Jones, R.L. (2017). The effect of $\beta$.alanine supplementation on neuromuscular performance. Ph. D. Thesis. Univ. Nottingham Trent: 204pp. 
Kambourova, M.; Tangney, M. \& Priest, F.G. (2001). Regulation of polyglutamic acid synthesis by glutamate in Bacillus licheniformis \& Bacillus subtilis. Appl. Environ. Microbiol., 67: 1004-1007.

Kim, S.; Kwon, D.; Kwon, D.; Paik, I. \& Hyuck, A.J. (2014). Optimizing carnosine containing extract preparation from chicken breast for anti-glycating agents. J . Food Sci., 34(1): 127- 132.

Krochta, J.M. \& Johnston, D.C. (1997). Edible and biodegradable polymer films: challenges and opportunities. Food Technol., 57: 335-343.

Mehran, M. (1976). Oil Testing. $1^{\text {st }}$ ed., Tehran Univ. Press: 263pp.

Mokhtar, S.M.; Youssef, K.M. \& Morsy, N.E. (2014) .The effect of natural antioxidants on colour, lipid stability and sensory evulation of fresh beef patties stored at $4^{\circ} \mathrm{C}$. J. Agro Processes Technol., 20(3): 282-292.
Ren, J.; Zhao, M.; Shi, J.; Wang, J.; Jiang, Y.; Cui, C. \& Xue, S.J. (2008). Purification and identification of antioxidant peptides from grass carp muscle hydrolysates by consecutive chromatography and electrospray ionization-mass spectrometry. Food Chem., 108(2): 727-736.

Sila, A. \& Bougatef, A. (2016). Antioxidant peptides from marine by-products. Isolation, identification and application in food systems. A review. J. Funct. Food, 21: $10-26$.

SPSS (2018). SPSS useri Guid statistics version 25. Copyright IBM, SPSS Inc.

Wang, B.; Gong, Y.D.; Li, Z.R.; Yu, D.; Chi, C.F.; \& Ma, J.Y. (2014). Isolation and characterisation of five novel antioxidant peptides from ethanol-soluble proteins hydrolysate of spotless smooth hound (Mustelus griseus) muscle. J. Funct. Food, 6: 176-185. 